\title{
Uncertain future for California's biomass power plants
}

Gareth Mayhead, Academic Coordinator, Center for Forestry, UC Berkeley Peter Tittmann, Postdoctoral Researcher, Institute of Transportation Studies, UC Davis

$\mathrm{B}$ iomass power plants convert organic plant matter such as sawmill residues, green waste, orchard prunings, nut shells and fruit pits into electricity. Despite policy changes that have made the economics challenging, California has the most biomass power plants of any state. Yet according to the California Energy Commission, biomass-derived power only contributes about $2 \%$ of the state's electricity.

Government incentives to develop renewable energy date to 1978, when Congress passed the Public Utilities Regulatory Policies Act (PURPA). A response to the 1970s oil crisis, PURPA aimed to reduce U.S. reliance on imported oil. California implemented PURPA to encourage biomass, wind and solar energy, leading to emergence of the biomass-to-electricity industry in the 1980s and early 1990s.

The California Renewable Portfolio Standard (RPS), created in 2002 and subsequently strengthened several times, now requires utilities to source $33 \%$ of electricity from renewable sources by 2020. In 2010, California's three largest Investor Owned Utilities (IOUs) procured 17\% of electricity from renewable sources, according to the state Public Utilities Commission. All new capacity brought online under the RPS in 2011 (830 megawatts) was either solar or wind - intermittent renewable energy sources that cannot provide consistent baseload power (the amount which utilities must make available to meet minimum demand, at all times on all days). With no new contracts, biomass-derived electricity appears to have less appeal to California utilities than it once did, when PURPA first passed.

\section{Current trends in biomass power in California}

Existing public information on solid-fuel biomass power plants in California is often outdated or difficult to access. Figure 1, a map developed by the Woody Biomass Utilization Group at UC Berkeley, shows the current status of the state's biomass-to-electricity industry. We attempted to identify all existing biomass power plants, whether currently operational or not. (Online map links to contacts.)

Of the existing 40 solid-fuel biomass power plants, 23 are currently operational, eight are idle, six are nonoperational and three are the subject of restart projects. There is one new proposed solid-fuel plant at a sawmill in Anderson. Many of the existing plants have suffered in recent years: They are locked into 30-year contracts with IOUs that pay them low prices for electricity produced, resulting in facilities shutting down for periods of time when they cannot afford to run. This has significant implications for the communities where these facilities are based, as they are often a major employer and contributor to the tax base.
In recent years, a number of attempts have been made to restart nonoperational facilities, which is significantly less expensive than building a new facility; in some cases this may be the only way to add biomass capacity since the old plant retains its original permits, and regulations make it difficult to get new permits. Another major trend has been in co-fire/conversion projects. Co-firing or conversion is direct substitution for fossil fuels and, similar to restarts, often makes financial sense. Developers restarting facilities, working on co-fire/conversion or building new projects have been able to negotiate new RPS contracts with the IOUs and receive higher prices for electricity than existing facilities, creating in effect a dual market. Despite the low electricity prices received, during the past year at least six of the existing power plants have been sold to investors. This trend may be driven by speculation that the IOUs will pay more for electricity as the 2020 RPS deadline approaches.

Three pilot projects are demonstrating gasification as a way to produce electricity from biomass at a smaller distributed scale (40 to 200 kilowatts [kW]) in addition to a small commercial unit $(500 \mathrm{~kW})$. All the small projects have faced significant challenges - both bureaucratic and financial - in connecting to the electricity grid. This is in contrast to the streamlined interconnection procedures available for small solar projects.

\section{A clean alternative}

Biomass power plants not only generate renewable baseload power, they offer a clean and cost-effective disposal option for biomass residuals from the agricultural, urban and forestry sectors while sustaining rural jobs and communities. For example, the U.S. Forest Service relies on the industry to take biomass material from National Forest System ecosystem restoration projects in California, helping to offset the cost to taxpayers. If the industry did not exist, the Forest Service believes that fewer acres would be treated, increasing catastrophic wildfire risks.

As people interested in California agriculture and forestry, we should recognize the environmental and social values of biomass-to-electricity. Regulators and policymakers could identify methods to recognize these co-benefits in the rates that utilities pay for electricity from biomass. The current rulemaking process for the Feed-in Tariff presents an opportunity to offer a higher price that would incentivize small-scale (less than 3 megawatts) biomass-to-electricity facilities. Reauthorization of the Public Goods Charge (a fee to electricity retail consumers that funds public programs including biomass research and development and existing biomass power plants), which expired at the end of 2011, would also help. Solar, wind and other sources are all part of a balanced energy portfolio; electricity rates should reflect the range of environmental and social cobenefits that biomass-to-electricity delivers in California. 


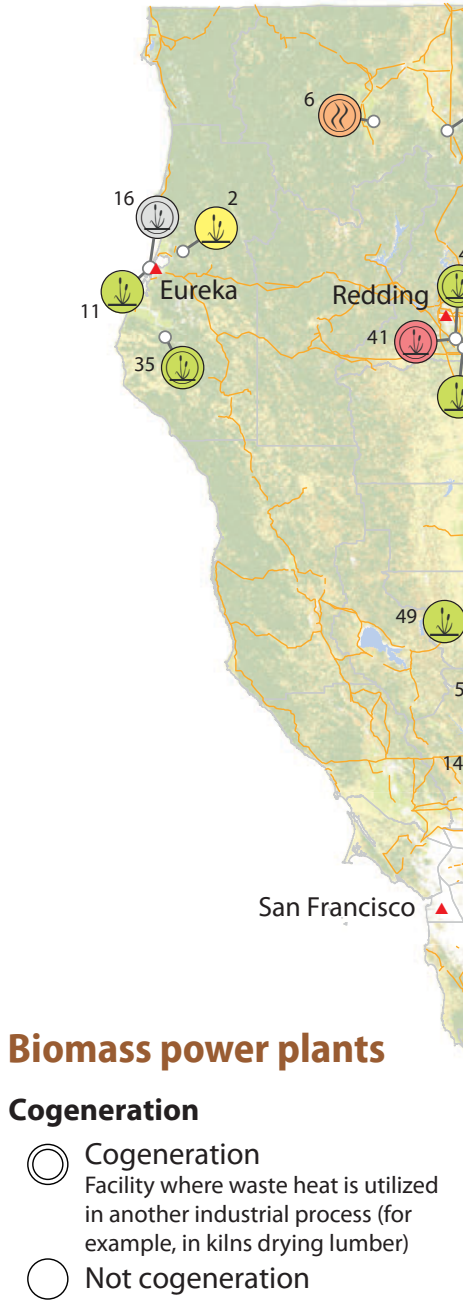

Plant type

Facility where waste heat is utilized
in another industrial process (for
example, in kilns drying lumber)
Not cogeneration
Iant type
(1) Biomass solid fuel
Traditional biomass power plants
Fo-fire or conversion from fossil fuels
include biomass as partial or total replacement fuel
(12) Gasification

Facility where waste heat is utilized
in another industrial process (for
example, in kilns drying lumber)
Not cogeneration
Bype
Biomass solid fuel
Traditional biomass power plants
Co-fire or conversion from fossil fuels
Fossil fuel-fired facilities that are converting to
include biomass as partial or total replacement fuel
Gasification

Facility where waste heat is utilized
in another industrial process (for
example, in kilns drying lumber)
Not cogeneration
Iant type
(1) Biomass solid fuel
Traditional biomass power plants
Fo-fire or conversion from fossil fuels
include biomass as partial or total replacement fuel
(12) Gasification

Facility where waste heat is utilized
in another industrial process (for
example, in kilns drying lumber)
Not cogeneration
type
Biomass solid fuel
Traditional biomass power plants
Co-fire or conversion from fossil fuels
Fossil fuel-fired facilities that are converting to
include biomass as partial or total replacement fuel
Gasification

Facility where waste heat is utilized
in another industrial process (for
example, in kilns drying lumber)
Not cogeneration
type
Biomass solid fuel
Traditional biomass power plants
Co-fire or conversion from fossil fuels
Fossil fuel-fired facilities that are converting to
include biomass as partial or total replacement fuel
Gasification

Facility where waste heat is utilized
in another industrial process (for
example, in kilns drying lumber)
Not cogeneration
Iant type
(1) Biomass solid fuel
Traditional biomass power plants
Fo-fire or conversion from fossil fuels
include biomass as partial or total replacement fuel
(12) Gasification

An alternative thermal process where biomass is converted to a gas used to fuel an internal combustion engine or turbine, generating electricity

\section{Status}

Active project (in transition)

New construction, conversion or restart under way

Idled

Temporary stoppage (months or longer) where

restarting would be a relatively simple process

Nonoperational

Facility has not operated for years and may require significant capital to restart

Operational

Pilot project

Small-scale demonstration

Proposed project

In planning

Fig. 1. Current status of California biomass power plants, 2011. One megawatt can power 800 to 1,000 homes.

\begin{tabular}{llc}
$\begin{array}{l}\text { Plant } \\
\text { ID }\end{array}$ & City & $\begin{array}{c}\text { Capacity } \\
\text { (megawatts) }\end{array}$ \\
\hline 1 & Bieber & 7.5 \\
2 & Blue Lake & 11.0 \\
3 & lone & 18.5 \\
4 & Burney & 31.0 \\
5 & Burney & 11.0 \\
6 & Etna & 0.041 \\
7 & Chowchilla & 12.5 \\
8 & Chester & 12.0 \\
9 & Mecca & 47.0 \\
10 & Delano & 50.0 \\
11 & Fairhaven & 18.0 \\
12 & Stockton & 4.5 \\
13 & Dinuba & 12.0 \\
14 & Winters & 0.05 \\
15 & Stockton & 45.0 \\
16 & Samoa & 50.0 \\
17 & Wendel & 32.0 \\
18 & Brawley & 18.0 \\
19 & Anderson & 31.0 \\
20 & Firebaugh & 28.0 \\
\hline
\end{tabular}

\begin{tabular}{llc}
$\begin{array}{llc}\text { Plant } \\
\text { ID }\end{array}$ & City & $\begin{array}{c}\text { Capacity } \\
\text { (megawatts) }\end{array}$ \\
\hline 21 & Mendota & 25.0 \\
22 & El Nido & 12.5 \\
23 & Brawley & 18.5 \\
24 & Bakersfield & 44.0 \\
25 & Westwood & 11.5 \\
26 & Oroville & 18.0 \\
27 & Jamestown & 22.0 \\
28 & Merced & 0.5 \\
29 & Truckee & 3.0 \\
30 & Fresno & 25.0 \\
31 & Bakersfield & 40.0 \\
32 & Bakersfield & 40.0 \\
33 & Rocklin & 25.0 \\
34 & Weed & 12.0 \\
35 & Scotia & 28.0 \\
36 & Auberry & 7.5 \\
37 & Terra Bella & 9.5 \\
38 & Soledad & 13.4 \\
39 & Burney & 20.0 \\
40 & Anderson & 4.0 \\
41 & Anderson & 6.0 \\
42 & Lincoln & 18.0 \\
43 & Loyalton & 20.0 \\
44 & Quincy & 25.0 \\
45 & Sonora & 8.0 \\
46 & Susanville & 12.5 \\
47 & Tracy & 19.4 \\
48 & Woodland & 0.2 \\
49 & Williams & 26.5 \\
50 & Stockton & 45.0 \\
51 & Anderson & 50.0 \\
52 & Woodland & 25.0 \\
\hline & & \\
\hline
\end{tabular}

